\title{
The Year 1970-A "Modest" Beginning For Monetary Aggregates
}

\author{
by JERRY L. JORDAN and NEIL A. STEVENS
}

\section{L} for the YLAR marked a transition for the economy, plementation - of these policies. At the beginning of 1970 , the nation was suffering from the continuation of inflation caused by the excesses of 1965 through 1968 , as well as weakness in production resulting from the corrective steps taken in 1969. Monetary policymakers were faced with the question of whether a growth rate of total spending could be achieved which would be conducive both to reduction of inflation and to renewed growth in production.

In the first two meetings of 1970 the Federal Open Market Committee, ${ }^{1}$ the primary monetary policy making group, decided to change the direction of its policy by moving cautiously toward a less restrictive policy. As the year 1970 progressed, real GNP declined slightly, unemployment rose considerably, and price increases tended to slow. ${ }^{2}$ Because of this sluggish performance of the economy, the Committee pursued a more expansionary policy through the year.

The method of implementing the Committee's policy decisions also was modified in 1970 , compared to the approach taken in the previous two decades. At the January meeting, the Committee stated its desire to have increased emphasis placed on achieving specific growth rates of certain monetary aggregates. The amount of emphasis given to achieving growth targets of the aggregates, however, varied considerably during the year.

This article examines and summarizes the monetary policy decisions of the Committee in 1970. The main source of information is the "Record of Policy Actions of the Federal Open Market Committee,"

The Federal Open Market Committee (FOMC) henceforth will be referred to as the "Committee" in this article.

asee Norman N. Bowsher, "1970-Economy in Transition," this Review (December 1970), pp. $2+13$ for a review of ecom nomic developments in 1970 . which is released to the public about 90 days after each meeting. ${ }^{3}$ The records include the directive to the New York Federal Reserve Bank, a summary of information reviewed by the Committee members, discussion of prevailing and prospective economic conditions, and a summary of the discussion on policy matters by the members.

\section{POLICY OBJECTIVES AND THEIR IMPLEMENTATION IN 1970}

The Committee's basic concern in the long run is the performance of the economy in terms of production, employment, prices, and the balance of payments. The variable over which the Committee has direct control, the buying and selling of Government securities, does not affect these ultimate objectives directly. Open market operations, however, affect various monetary and financial variables, including the money stock, bank credit, and market interest rates. These variables, in turn, affect the spending decisions of consumers and businesses, and ultimately influence production, employment, prices, and the balance of payments.

\section{Interest Rates and Monetary Aggregates}

In general there are at least two broad views concerning the manner in which Federal Reserve policy actions are transmitted to the economy. Each view has associated with it an indicator which measures the thrust of monetary actions on the ultimate policy goals. ${ }^{4}$ The first view emphasizes interest rates, and the second emphasizes the money supply.

The interest rate approach uses market interest rates as the indicator of the effect of policy actions on

\footnotetext{
All quotes in this paper are from these records unless specified otherwise.

${ }^{4}$ See Albert F. Burger, "The Implementation Problem of Monetary Policy," this Review (March 1971), pp. 20-30, for a detailed discussion of the indicator problem.
} 
ultimate objectives. In general, followers of this approach believe that Federal Reserve actions dominate movements in interest rates, and that policy actions are transmitted through interest rates to investment and consumption expenditures, and thus the ultimate policy objectives.

The Federal Reserve does not control interest rates rigidly. Day-to-day open market operations are determined by looking at money market conditions, which include such measures as free reserves, member bank borrowings, the Federal funds rate, Treasury bill rates, and the attitudes of major market participants. Using these measures as "gauges," the Federal Reserve can affect the amount of "pressure" or "ease" in the market, thereby influencing interest rates in the desired direction.
An alternative approach to economic stabilization uses the money supply as the main indicator of the thrust of policy actions on economic activity. According to this view, changes in the nation's money stock have a substantial influence on the growth of total spending in the economy over a year or more. It is contended that policy actions should be directed towards maintaining relatively stable growth of the money stock in order to achieve a long-run growth of total spending which is consistent with full employment and stable prices.

Supporters of this view believe that changes in the public's demand for credit dominate movements in market interest rates, and that the present demand for credit is outside the direct control of the Federal Reserve. It is held that current actions of the Federal

\section{Federal Open Market Committee in 1970}

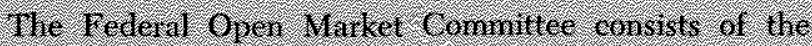

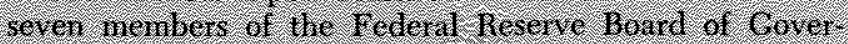

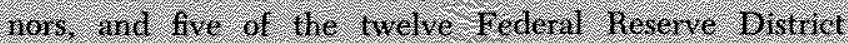

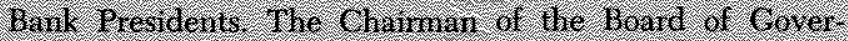

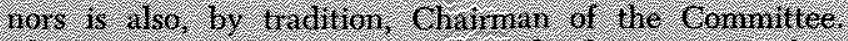

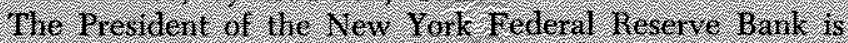

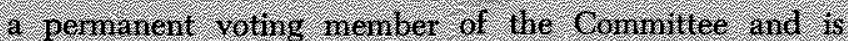

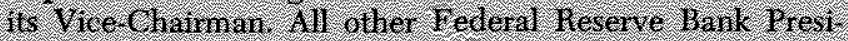

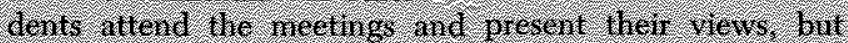

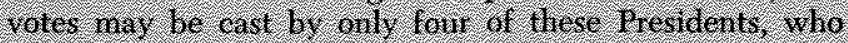

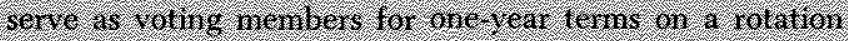
Basis:

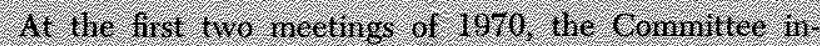

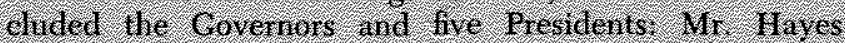

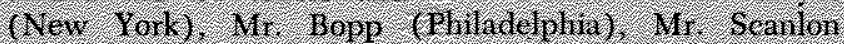

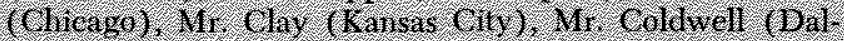

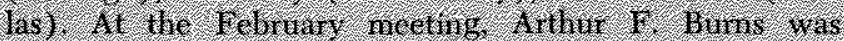

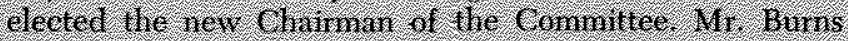

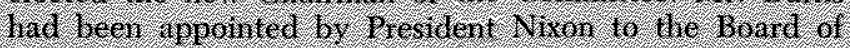

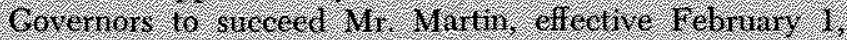

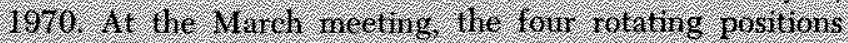

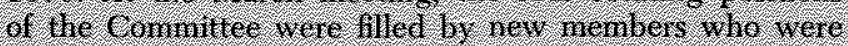

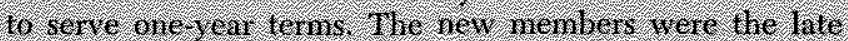

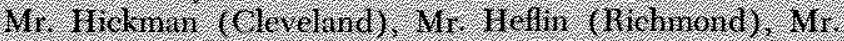

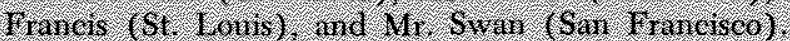

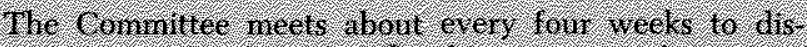

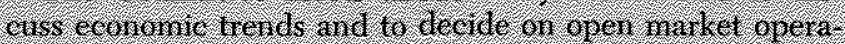

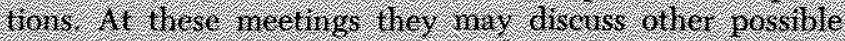

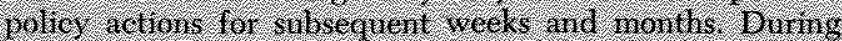

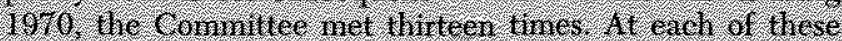

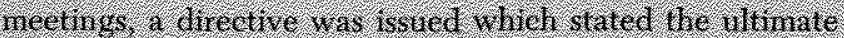

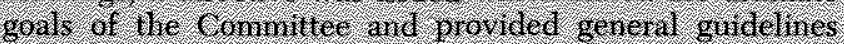

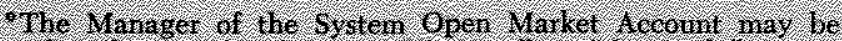

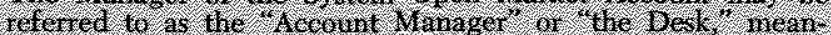

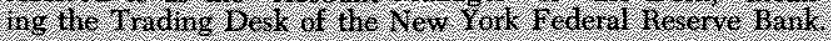

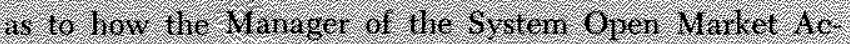

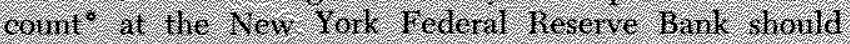

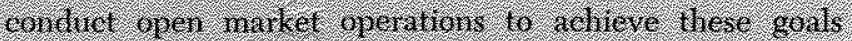

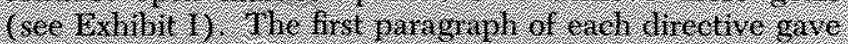

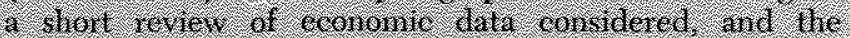

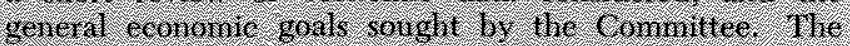

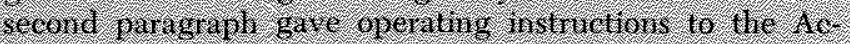

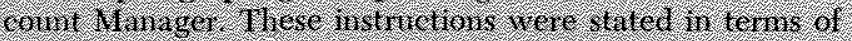

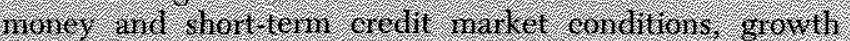

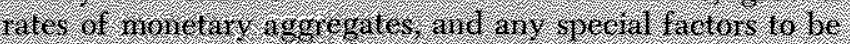

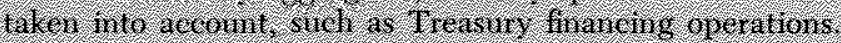

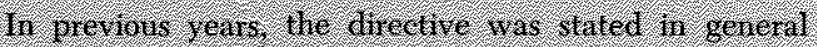
terns whict proviled th outline by whith the nesk

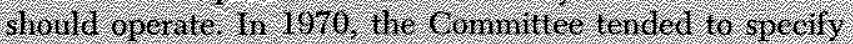

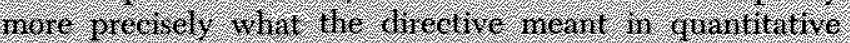

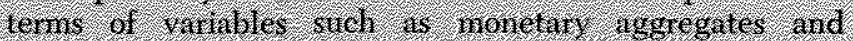

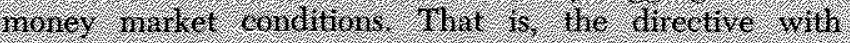

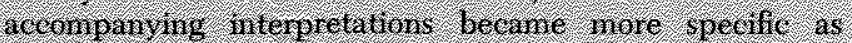

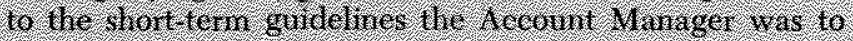

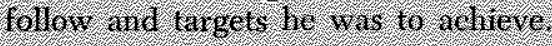

The tecisitns on the uning and anount of darly buy

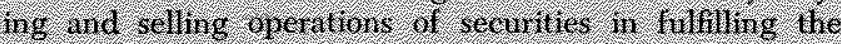

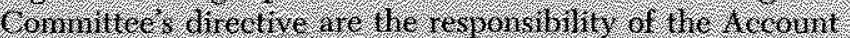

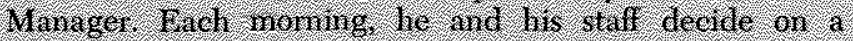

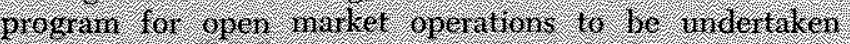

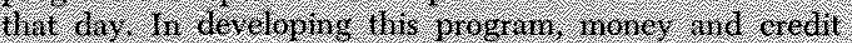

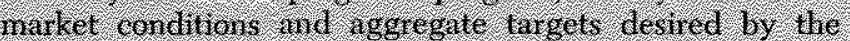

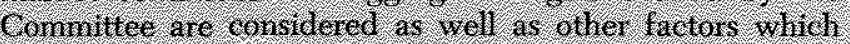

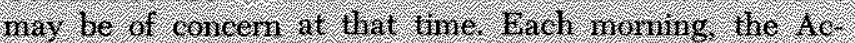

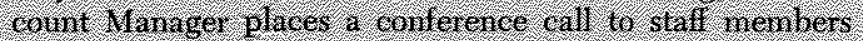

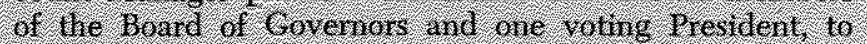

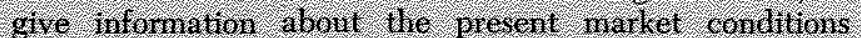

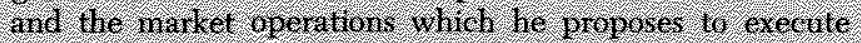

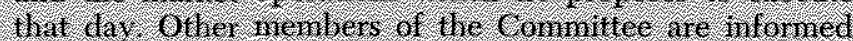

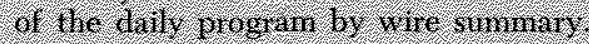




\section{FEDERAL OPEN MARRET COMMUTREE ECONOMIC POLCY DIRECTVES}

Date of
FomC Meeting

\section{Policy Consensus}

In light of the foregoing developments, it is the policy of the Federal Open Markel Committee to foster financial conditions conducive to the orderly reduction of inflationary pres. sures, with a view to encouraging sustainable economic growth and attaining reasonabit equilibrium in the country's balance of payments.

Dissents:

February 10 No Change
Dissents:
Mr. Hayes
Mr. Brimmer
Mr. Coldwell

In light of the foregoing developments, it
is the policy of the Federal Open Market Com-
mittee to foster financial conditions conducive to
orderly reduction in the rate of infation, white
encouraging the resumption of sustainable eco-
nomic growth and the attainment of reasonable
equilibrium in the country's balance of
payrients.
Dissents:

Dissents :

\begin{tabular}{cc} 
None \\
\hline April $7 \quad$ No Change \\
Dissents: \\
None
\end{tabular}

May $5 \quad$ No Change

Mr. Francis

May $26 \quad$ No Change

\section{Operating Instructions}

To implement this policy, while taking account of the forthcoming Treosury refunding, possible bank regulatory changes and the Commiftee's desire to see modest growth in money and bank credil, System open market operations until the next meeting of the Committee shall be conducted with a view lo maintaining firm conditions in the money market;

\section{Proviso Clause of Directive}

provided, however, that operations shall be modified if maney and bank credif appear to be deviating significantly from current projections.
... While taking account of the current Treasury refunding possible bank regulatary changes and the Committee's desire to see moderate growth in money and bank credit over the months aheod, System open markel operations until the next meeting of the Commiftee shall be conducted with a view to moving gradually toward somewhat less firm conditions in the money market;

... the Committee desires to see moderate growth in money and bank eredit over the months ahead. System open market operations until the next meeting of the Commitlee shall be conducted with a view to maintaining money market conditions consistent with that objective. provided, however, that operations shall be modified promply to resist any tendency for money and bank credis to deviate significanty from a moderate growth pottern.

no proviso clause
... the Commitiee desires to see moderate growth in money and bank credit over the months ahead. System open market operations until the next meeting of the Committee shall be conducted with a view to maintaining laking account of the fortheoming Treasury financing.

... the Committee desires to see moderate growth in money and bank credit over the months ahead. System open markel operations until the next meeting of the Committee shall be conducted with a view to maintaining bank reserves and money markeł conditions consistent with that objective, faking account of the current Treasury finaneing

... in view of current market uncertainties and liquidity strains, apen market aperations until the next meeting of the Committee shall be conducted with a view to moderat ing pressures on financial markets, white, to the extent compatible therewith, maintaining bank reserves and money market conditions consistent with the Committee's longer-run objectives of moderate growth in money and bank credit.

\section{no proviso clause}

provided, however, that operations sthall be modified as needed to moderate excessive pressures in financial markets, should they develop.

no proviso clause 
Dissents:

None
June 23 No Change

.. in view of persisting market uncertainties and liquidity strains, open market operafions unfil the next meeting of the Commiftee shall continue to be conducted with a view to moderating pressures on financial markets. To the extent compatible therewith, the bank reserves and money market canditions maintained shall be consistent with the Committee's longer wun objective of modertate growth in money and bank credit, taking account of the Board's regulatory action effective June 24 and some possible consequent shifting of eredit fows from market to banking channels.

No Change
Dissents:
None

None

... while taking account of persisting market uncertainties, liquidify strains, and the fortheoming Treasury financing, the Committee seeks to promote moderate growth in money and bank credil over the months ahead, allowing for a possible conthued shith of credn hows hom markel to banking channels. System open maket aperations unt the next meeting of he con bank shal be conducted mather conditions consistent with that objective market conditions consistent with that abjective,

August 18 No Change

Mr. Hoyes

Mr. Brimmer

Mr. Frantis

con the Committee seeks to promote some easing of conditions in credit markets and somewthat greater growth in money over the months ahead than occurred in the problems and, while taking account of possible liquidity contiryed shift of credit flows from market to banking channels. System open markef operations until the next meeting of the Committe shall be conducted with a view to maintaining bank reserves and money markel conditions consisfent with that objective, taking account of the effects of other monetary policy actions.

\section{September 15 No Change}

Mr. Hayes

October 20 No Change

Mr. Hayes

November 17 No Change

$$
\begin{aligned}
& \text { Dissents: } \\
& \text { Mr. Maisel }
\end{aligned}
$$

December 15 No Change

Dissegts:
Mr. Francis

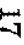

the Commiltee seeks to promote some easing of conditions in credit markets and moderate growth in money over the months ahead. System open morket operation difions consistent with that oblective.

.. The Committee seeks to promole some easing of conditions in credil markets and moderate growth in money and altendant bank credit expansion over the months ahead. System open market operations until the next meeting of the Commillee shall be conducled with a view to mainfainiting bank reserves and money morket condifions consistent with those objectives, taking account of the forthcoming Treasury financings.

- . the Committee seeks to promote some easing of conditions in credit markets and moderate growth in money and aftendant bank credit exponsion over the months ahead, with allowance for temporary shifts in money and credit demands related to the auto strike. the Committe shall be conducted with a view to pining bank reserves and money market conditions consistent with those objectives.

... System open market operations shall be conducted with a view to maintaining the recently atkained money market conditions until the next meeting of the Commitfee, no proviso clouse

provided, however, that operations shall be modified should they develop.

no proviso clause

no proviso clause

no proviso elause

no proviso clause

provided that the expected retes of growth in money and bank credit will at least be achieved. 
Reserve influence the public's future demand for credit through its delayed influence on total spend. ing. Such lagged effects of previous policy actions result in current interest rates giving misleading information about the effects of monetary actions on total spending.

For instance, when an economic recovery is occurring, rising interest rates reflect a growing demand for credit, as business firms seek to expand productive capacity and build inventories. If policymakers view the rising interest rates as being restrictive, they may attempt to direct open market operations to resist the tightening of credit conditions, in order to stabilize or slow the rise in interest rates. To accomplish this, reserves would have to be supplied at rapid rates, resulting in an accelerating growth rate of the money stock. After some time lag, the rapid growth in money would induce further acceleration in growth of total spending, resulting in inflation and even higher interest rates as an inflation premium becomes built into market interest rates.

Before 1970, the Committee followed more closely the money market conditions approach of implementing its policy decisions. In 1970, more emphasis was placed on monetary aggregates. However, according to an article in the February 1971 Federal Reserve Bulletin, the increased emphasis on aggregates since early 1970 "is consistent with a variety of economic theories, and does not necessarily imply any particular judgment as to the importance for the economy of monetary flows relative to interest rates and credit conditions or relative to other inftuences such as fiscal policy and technological innovation." 5

In 1970, a hybrid approach was employed of controlling money market conditions on a day-to-day basis with a view to controlling monetary aggregates over the longer term. According to this approach, the growth of the demand deposit component of the money stock can be influenced by appropriate adjustment of money market pressures. The central idea is that the demand for money is influenced by interest rates as well as so-called transactions needs of the public, and that money market pressures can be controlled in such a way to achieve a desired growth of deposits.

At the January 1970 meeting, the Committee explicitly stated its desire to have more importance placed on achieving growth rates of monetary aggregates when conducting open market operations. A

$\overline{5}^{\prime \prime}$ Monetary Aggregates and Money Market Conditions in Open Market Policy," Federal Reserve Bulletin (February 1971), p. 86 . principal change in the implementation of policy, which accompanied the greater attention on monetary aggregates, was that the Committee adopted a somewhat longer horizon in specifying the desired changes in policy variables. Specifically, quarterly goals for money ${ }^{6}$ were set at the meeting preceding each quarter and reviewed as the quarter progressed. This longer time horizon allowed greater flexibility in attaining the money and bank credit targets, while avoiding excessive short-run fluctuations in interest rates.

\section{Modifying Objectives}

Although the Committee put more emphasis on achieving desired growth rates of monetary aggregates, other short-run objectives were specified in most directives, as was done in the past. In addition to policy goals regarding production, prices, employment and the balance of payments, the Federal Reserve has generally assumed responsibility for maintaining orderly and smoothly functioning money markets. This responsibility is assumed, partly because orderly market conditions are considered desirable by some in order to successfully achieve the objectives of the Committee. According to the Federal Reserve Bulletin, "the nation's central bank has a unique responsibility for maintenance of orderly conditions" 7 in the money market. One interpretation of this objective is that disorderly markets might develop in absence of the Federal Reserve's efforts.

In accord with this self-imposed objective, emphasis on aggregates received secondary importance when conflicts arose. For instance, at the late May meeting and the June meeting, the Committee was largely concemed with excessive pressures in credit markets, and directed that open market operations be conducted so as to moderate such conditions. Many followers of the money supply approach, however, believe that the Federal Reserve System can make its greatest contribution toward avoiding disorderly market conditions by keeping the growth of money in a moderate range.

Most directives in 1970 also called for other items to be taken into account as open market operations were carried out. Five directives called for specific consideration of either regulatory changes (Regulations $D$ and $Q$ ) or the shifts in funds from market to banking channels caused by changing relationships between Regulation Q ceilings and market interest rates.

\footnotetext{
TTargets for bank credit were also given at some meetings, but, in general, money was the dominant aggregate target. "Monetary Aggregates and Money Market Conditions in Open Market Policy," p. 94.
} 
During 1970, six directives called for the Account Manager to consider "forthcoming" or "current" Treasury financings. Historically, the Federal Reserve has assumed some responsibility in keeping market conditions conducive to the success of Treasury financings, often referred to as "even-keel" operations. The objective of "even-keel" operations is to stabilize money market conditions during the period between the Treasury's announcement of a security offering and their sale, and thus to maintain an orderly and receptive market for these securities. In effect, the Federal Reserve may buy securities in the market while the Treasury is selling. Particular emphasis was placed on even-keel operations in late April and in May of 1970, "when it appeared that the Treasury"s cash financing might be in jeopardy."

\section{Achieving Targets for Monetary Aggregates}

In carrying out day-to-day open market operations in 1970 , the Desk relied mainly on money market conditions. ${ }^{8}$ On a daily basis, the Desk concentrated principally on the Federal funds rate, which was thought to be consistent with the desired target growth rates for the monetary aggregates. By maintaining the Federal funds rate in a prespecified range, an attempt was made to obtain the desired growth of aggregates. This approach implies that the quantity of securities purchased by the Desk is not as important in influencing the near-term growth of money as the effect of these actions on money market conditions.

Uncertainties surrounding a revision of the money stock series caused difficulties for policymakers in 1970. In the latter half of 1970 , it became known that a measurement error arising from certain international transactions was contained in the money series. ${ }^{9}$ The revised series was available to the Committee in completed form at the November meeting, but at the preceding two or three meetings, the Committee had only a rough idea of the magnitude of the underestimation of money growth indicated by the old money series $^{10}$

sIbid., p. 94, for a rationale for continuing the use of money market conditions. Also see Paul Meek and Rudolf Thumberg, "Monetary Aggregates and F"ederal Reserve Open Market Operations," Monthly Review, Federal Reserve Bank of New York (April 1971), pp. 80-89.

For a detailed explanation of the revision, see Albert $E$. Barger and Jerry L. Jordan, "The Revised Money Stock: Explanation and Illustrations," this Review (January 1971), pp. 6-15.

10)Because of the revision, three money series are used in this paper: old, revised, and roughly adjusted. Unless otherwise specified, references to money will be the old series.

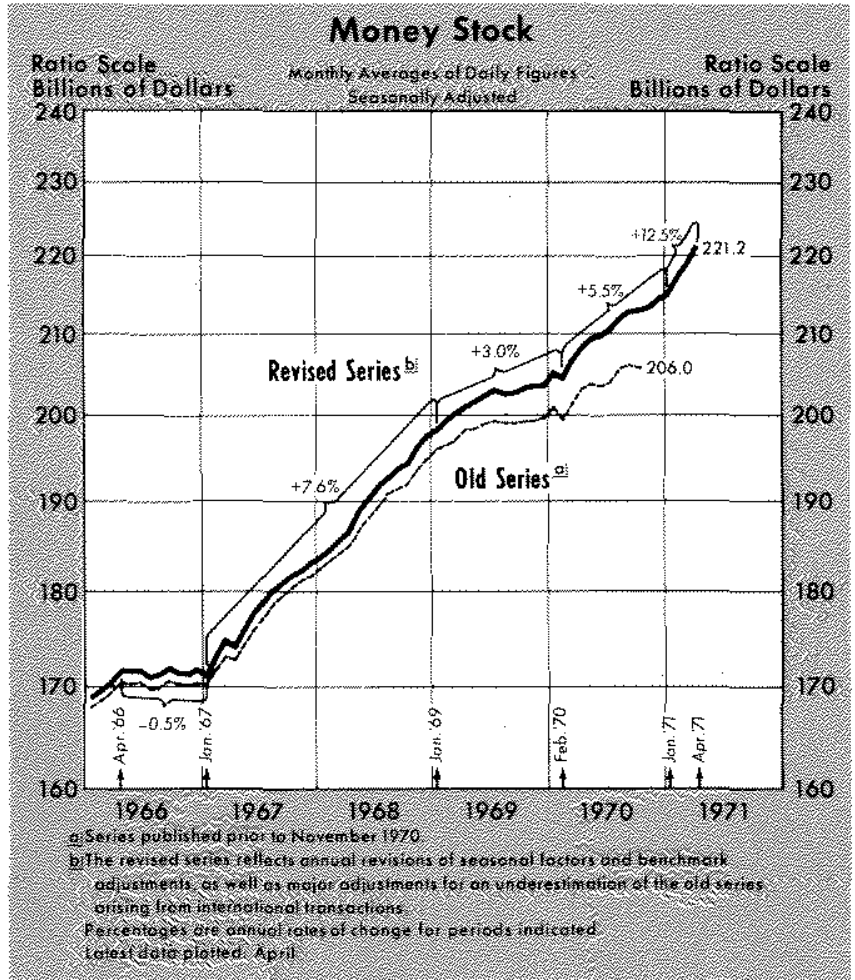

Initially, it appeared that in the first three quarters of 1970 , money growth had been in the range desired by the Committee, but the revised series indicated that money had grown more rapidly than desired. For instance, the old money series grew at a 4.4 per cent amual rate during the first three quarters of 1970 , compared with a 6.1 per cent rate for the revised series. At the September meeting, some members expressed the view that "it would be desirable to place less emphasis on a specific growth rate for the money stock."

The experience in 1970 suggests that some improvement in technique may be needed in controlling aggregates. The following bar chart shows actual growth rates of money as measured by the old and revised series, compared to that desired by the Committee in the four quarters of 1970 . Better control over monetary aggregates might have been achieved by a more direct method, such as by concentration on bank reserves or the monetary base, rather than the state of money market conditions.

\section{FDERAL ORN MARET COMMTTEE DECISIONS IN 1970}

This section presents a summary of the 1970 policy decisions of the Committee. The discussion outlines the economic data and forecasts available to the Committee at the time of each meeting and the policy decisions at each meeting. The policy directives of the 


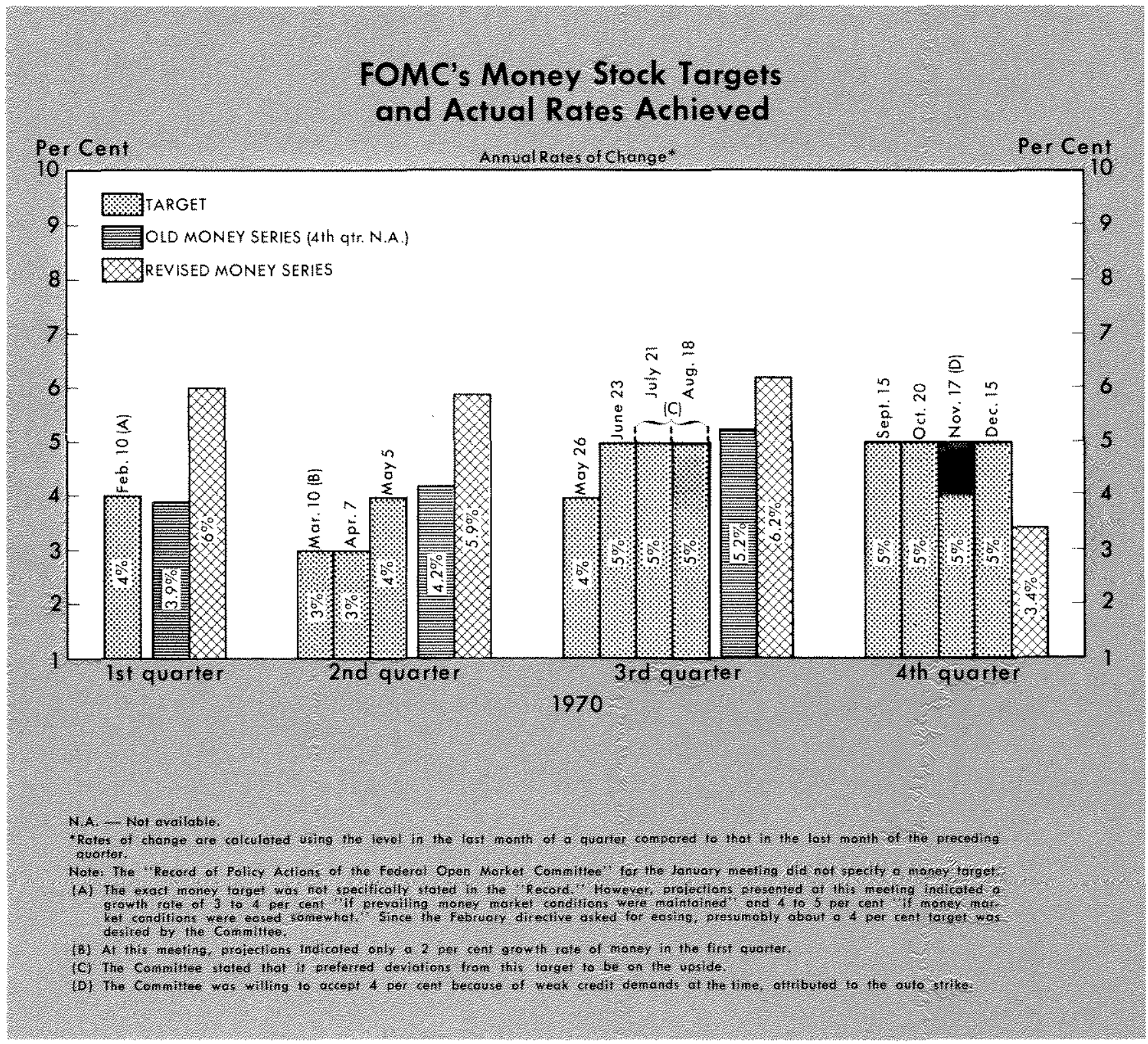

Committee for 1970 can be divided into four periods. January through April entailed the important decisions to move toward more emphasis on monetary aggregates in implementing monetary policy and to pursue a more expansionary monetary policy than was sought during 1969. May through July was characterized by pressures in financial markets and subsequent subordination of monetary aggregates in an effort to maintain money market conditions conducive to some easing of strained market conditions. From August through November, the Committee reinstated target growth ranges of monetary aggregates and, in addition, specifically called for some casing in money and credit markets. In December, the Committee moved towards less emphasis on monetary aggregates and more emphasis on money market conditions.

\section{January through April: Emphasis on Monetary Aggregates}

The Committee gradually moved toward a more expansionary policy in this period. Many members were concemed about a possible renewal of inflationary expectations if easing came too fast or was too pronounced. In addition to changing the direction of monetary policy action, the Committee also stated its desire to have more emphasis placed on monetary aggregates in the formulation and implementation of policy. 


\section{Economic Outook and Policy Decisions of the Commitue}

January 15 Meeting - Available data showed that real GNP had not grown in the fourth quarter of 1969 , industrial production had fallen for five consecutive months, and prices were still rising rapidly. Board of Governors staff projections noted that prospects were for "little change in real economic activity in early 1970." The staff also projected that prices would continue to rise rapidly, with perhaps some moderation as the year progressed. Some expansionary elements were noted, including plans by businesses to increase expenditures on new plant and equipment in 1970 , reduction of the income tax surcharge from 10 to 5 per cent on Jantary 1 and its elimination on July 1 , and the 15 per cent increase in social security benefits as of January 1.

Although the Committee was aware of the reduced level of economic activity, it was "agreed that any marked relaxation of monetary restraint would be premature at present in light of the persistence of inflationary pressures and expectations." The main concerns of Committee members continued to be inflation, and the need to show the public a willingness to persist in its restrictive policies until there was evidence that real progress against inflation was being attained.

Staff projections suggested that there would be little change in money and some decline in bank credit if prevailing money market conditions and Regulation $Q$ ceilings were maintained. Members expressed considerable concern over these prospects and disagreed

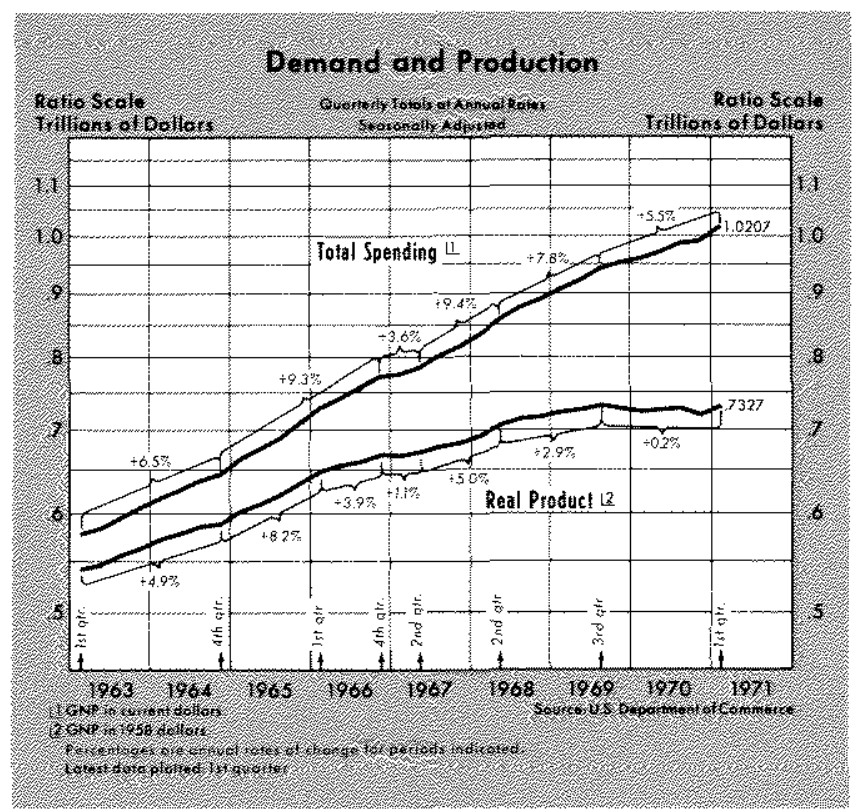

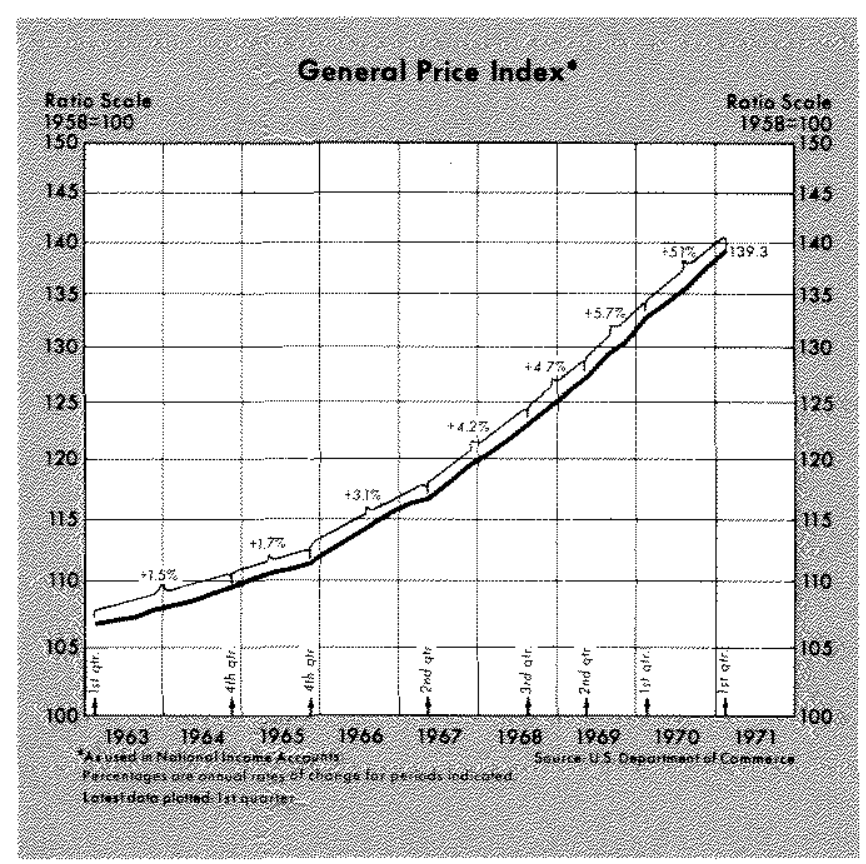

over the course of action that should be taken. Some members wanted money market conditions to remain "sufficiently firm to be consistent with a posture of monetary restraint," but "likely to be conducive to modest growth in bank credit and the money stock over the first quarter." Other members wanted the main emphasis put on a relaxation of Regulation $Q$, and some favored "maintaining the prevailing conditions in the money market."

The final decision of the Committee was to place increased emphäsis on "the objective of achieving modest growth in monetary aggregates" giving "about equal weight" to bank credit and the money stock. The Committee continued in a way similar to the past, by directing that open market operations should be conducted "with a view to maintaining firm conditions in the money market." "I The Committee also added a proviso clause in the January directive, stating "that operations shall be modified if money and bank credit appear to be deviating significantly from current projections." In view of the Committee's desire to pay more attention to aggregates, presumably the proviso clause was to be invoked sooner and more vigorously than in the past.

It was noted that the Board of Governors planned to consider raising Regulation $Q$ interest rate cellings

\footnotetext{
11 Presumably, firm conditions did not mean prevaling conditions, but some slight easing, since the staff had projected no growth in money and a decline in bank credit if prevailing money narket conditions were maintained. But most members were apparently unwilling to specify an actual easing of market conditions in the directive at this time because of the continued rapid rise in prices.
} 
EXHIBIT II

\section{MAJOR FEDERAL RESEVE ACTIONS OTHER THAN OPEN MARKT OPERATIONS IN 1970}

\section{Date of Announcement}

January 20

(Effective January 21 )

June 23

(Effective June 24 )

August 17

(Effective in the reserve computa-

tion period beginning October 1]

November 10

(Effective at all Reserve Banks by November 16 !

November 30

(Effective at all Reserve Banks by December 111

\section{November 30}

(Effective in the 4-week reserve computation period ending Decem. ber 23)

\section{Nature of Action}

Effect of Action

The Board of Governors raised maximum interest rales payable on time and savings deposits (Regulation $Q$ )

The Board of Governors suspended Regulation $Q$ ceilings on large certificates of deposit and other single-mafurity time deposits of 30 . to 89 -day maturities.

The Board of Governors placed reserve requirements (Regulation D) on funds obtoined by member bonks through the issuance of commercial paper by their affiliotes. The Board also reduced reserve requirements from 6 to 5 per cent on time depostis in excess of $\$ 5$ million.

The Board of Governors approved a reduction in the discount rate by Reserve Banks from 6 to $5 \%$ per cent.

The Board of Governors approved another reduction in the discount rate by Reserve Banks from $5 \frac{3}{4}$ to $5 \frac{1}{2}$ per cent.

The Board of Governors raised reserve requirements from 10 per cent to 20 per cent on Eurodallar borrowings the exceed the "reserve-free" base.
This action allowed saving funds to re-enter banking channels, thus encouraging growth of mare broadly defined aggregates such a bank credil and money stock plus time deposits.

This action wos taken by the Board in an effort to allow banks to be in a position to accommodate business customers unable to obtain funds in the commercial paper market, which of the time was under stress. The effect was to encourcge growth of large $C D$ 's.

By these actions, large certificates of deposit ond funds obtained by banks through issuance of commercial poper by their affiliates were placed on equal terms. Subsequently, bank-related commercial paper declined rapidly.

This action brought the discount rate into closer alignment with markef rates which had fallen substantially.

This action also brought the discount rate more in line with the rapidly falling short-term interest rates.

The action was intended to help the balance of poyments by discouraging banks from reducing theif Eurodollar borrowings below their reserve-free bose. 
soon. Effective January 21, 1970, the Board raised ceilings on time and savings deposits. The effect of this change was to encourage growth in bank credit and other broadly defined aggregates (see Exhibit II). In 1969, disintermediation of time deposits from banks as well as other financial intermediaries had occurred as market interest rates rose above Regulation $Q$ ceilings. Most of these funds were simply channeled to other market instruments, such as commercial paper, and to that extent did not affect total credit in the economy. The increase in Regulation $Q$ ceiling rates encouraged a rechanneling of funds back into banks. This outflow and inflow of time deposits during 1969 and 1970, however, distorted the growth rates of broadly defined aggregates such as money stock plus net time deposits, making interpretation of these series less meaningful as indicators of monetary influences,

February 10 Meeting - Evidence of further weakening in the economy was presented, although it was expected that some real growth would occur in the second half of the year. Weakness in the labor market was becoming evident, as unemployment rose from 3.5 per cent in December 1969 to 3.9 per cent in January 1970.

The Committee agreed that "it was appropriate to move gradually toward somewhat less restraint at this time." The directive issued to the Desk called for both "moderate growth in money and bank credit over the months ahead" and "somewhat less firm conditions in the money market." The word "moderate" meant a faster rate of growth for aggregates than the "modest" growth called for at the January meeting.

Three members of the Committee, Mr. Hayes, Mr. Brimmer, and Mr. Coldwell, dissented from the February directive. They believed that "any overt move toward less firm money market conditions was premature at this time and could strengthen market expectations of substantial easing." They stressed the continuing inflationary pressures, business plans for large volume capital spending, and the prospectively large balance-of-payments deficit. Although they agreed that some growth in money and credit was desirable, they preferred a directive similar to January's which called for "firm" money market conditions along with some growth in aggregates.

March 10 and April 7 Meetings - At these meetings, important changes in the wording of the directive were made, clarifying the meaning of the new attention to aggregates. Although the earlier directives of 1970 gave increased importance to the money stock and bank credit, they continued to be stated in terms of money market conditions, with an appended proviso clause regarding the aggregates. In the March and April meetings, an objective with respect to money market conditions was not specified in the directives. Rather, the wording of these directives indicated a willingness on the part of the Committee to

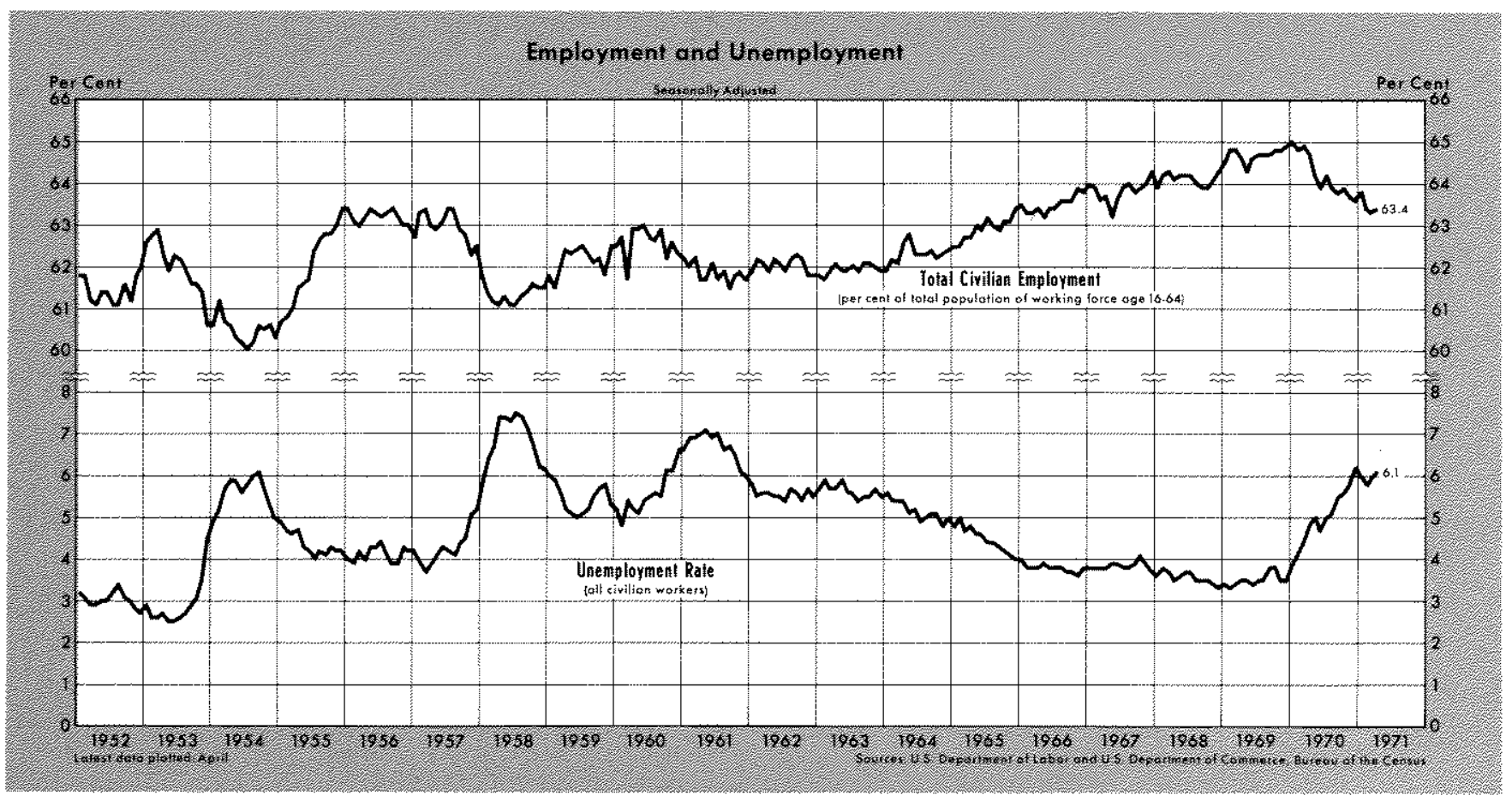




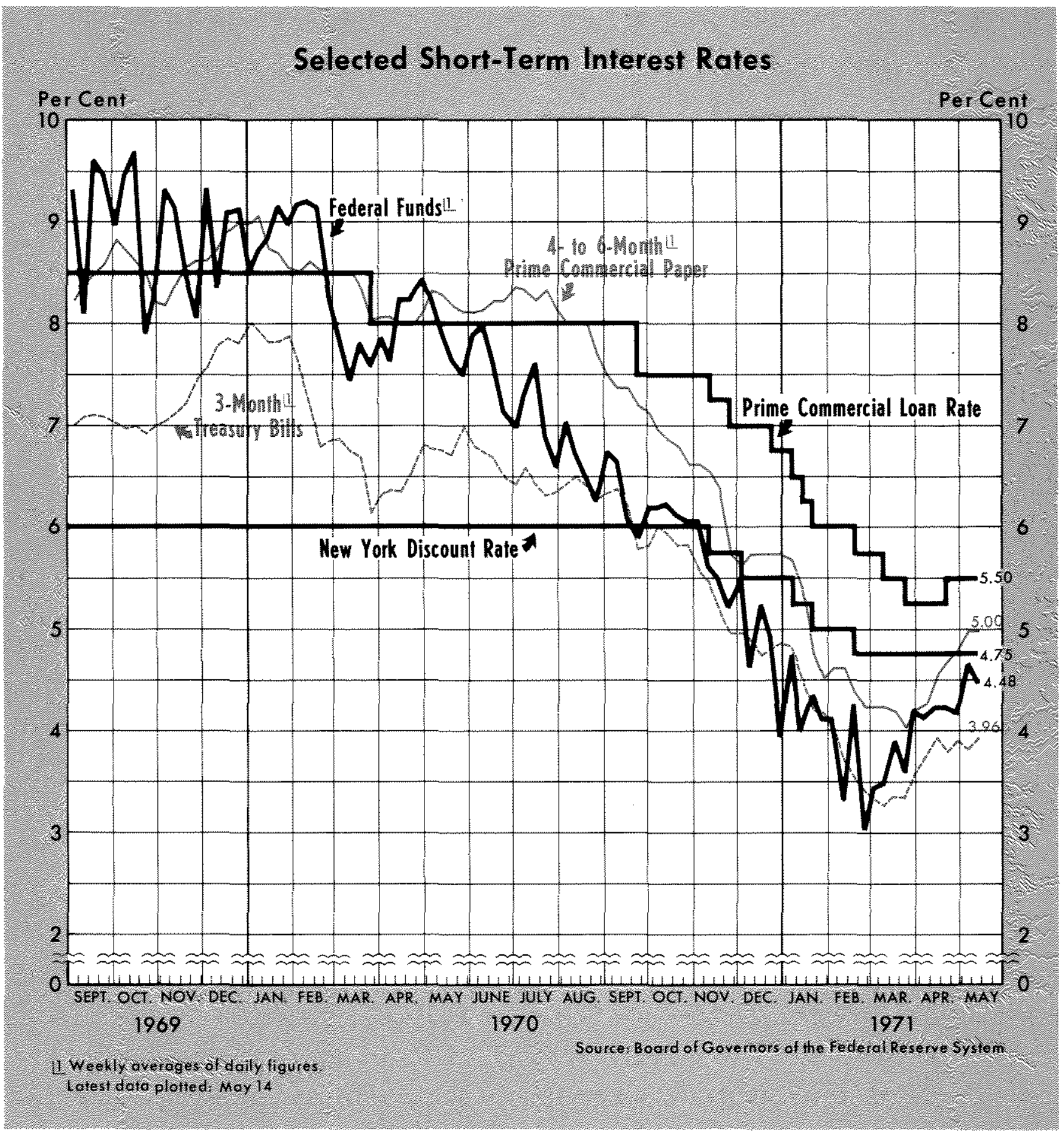

allow money market conditions to fuctuate if necessary, in order to attain desired money and bank credit growth targets. The March directive stated:

... the Committee desires to see moderate growth in money and bank credit over the months ahead. System open market operations until the next meeting of the Committee shall be conducted with a view to maintaining money market conditions consistent with that objective.
The growth targets for the money stock at the March meeting called for a 2 per cent annual growth rate in the first quarter (December 1969 to March), and a 3 per cent rate in the second quarter (March to June). At the April meeting, a 3 per cent growth target for the money stock was reaffirmed as the appropriate rate for the second quarter. 


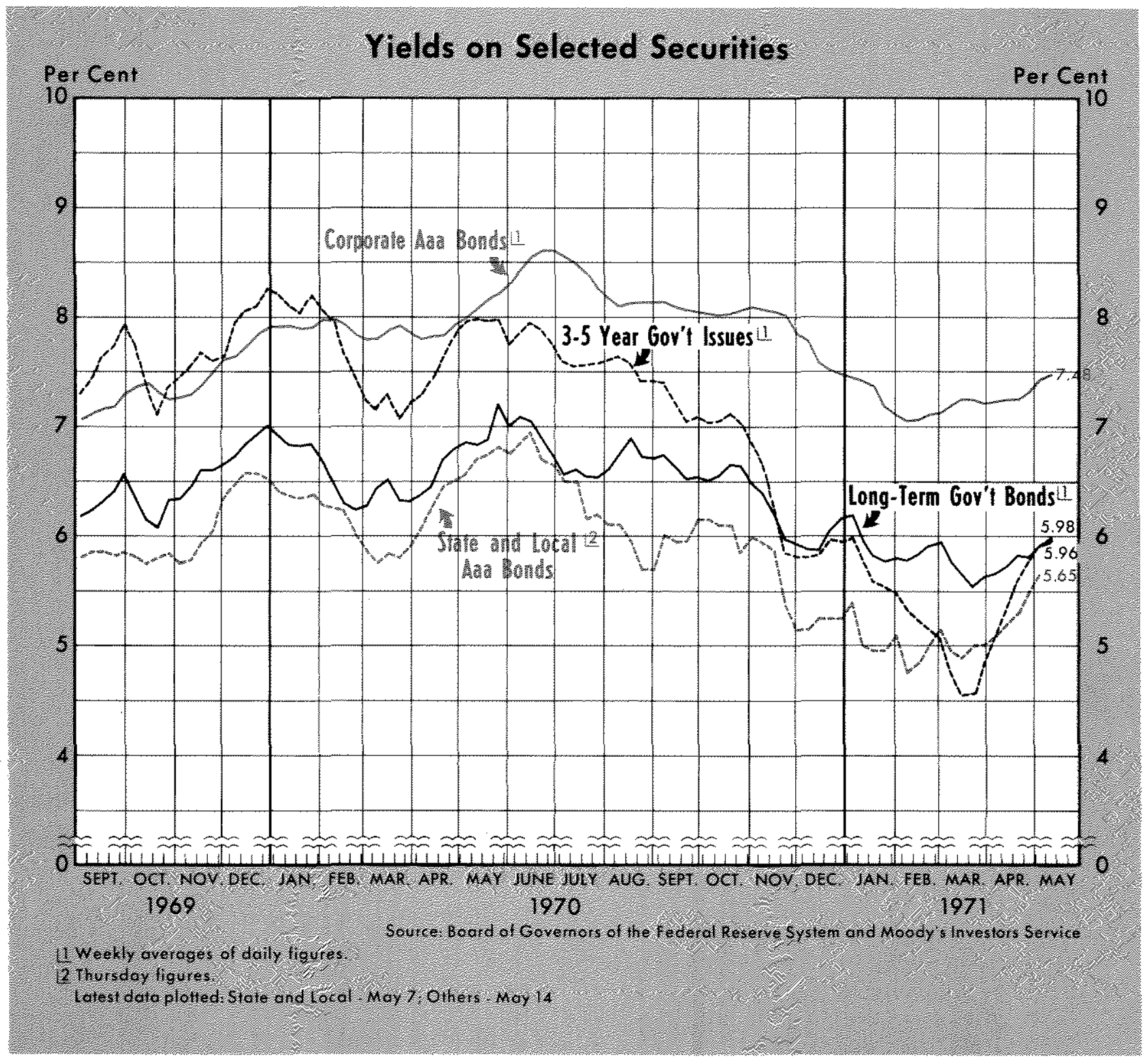

Although as a whole the Committee showed increased willingness to let money market conditions fluctuate in achieving aggregate targets, some members at the April meeting expressed concem about the possibility of wide fluctuations in money market conditions. It was noted that "precise achievement" of targets for growth of monetary aggregates "could not be expected, in part because of the desirability of avoiding excessive fluctuations in money market conditions and in part because of uncertainties regarding future relationships among financial variables." This view is in keeping with the February 1971 Bulletin article:

... whatever longer-run path for the aggregates may be included as guidance for open market operations, short-run, self-correcting variations in money and credit demands need to be accommodated in order to avoid inducing unnecessary, and possibly destabilizing, fluctuations in money market conditions. ${ }^{12}$

\section{Money Market Developments and Monetary Aggregates}

Money market conditions, measured by movements in short-term interest rates, eased on balance from January through April, as some growth in monetary aggregates was sought. The monetary base, the main determinant of the growth trend of the money stock, grew at a 6.7 per cent annual rate from December 1969 to April

12"Monetary Aggregates and Money Market Conditions in Open Market Policy," p. 80. 
1970. The money stock grew slowly in the first part of this period, but grew very rapidly in late March and in April. On balance in the period, money grew at a 5.7 per cent annual rate from December 1969 to April 1970.

Analysis given at the March meeting indicated that further easing actions would be necessary to achieve even a 2 per cent rate of growth of money in the first quarter and a desired 3 per cent rate in the second quarter. Money market conditions eased further after the March meeting, and staff projections showed that growth rates of aggregates were falling short of the Committee's desired rates. Later in the month, estimates of money growth were revised upwards, and the Committee no longer sought easing of money market conditions to promote growth of money. The money stock jumped sharply upward in the last week of March, due to technical factors involving a four-day Easter holiday abroad. With this bulge, money grew at a 3.9 per cent rate in the first quarter (December to March), almost double the expected 2 per cent rate at the time of the March meeting and higher than the 3 per cent rate desired by the Committee for the second quarter.

The Committee thus showed considerable concern for the achievement of the growth targets for monetary aggregates in early 1970 , especially the money stock. This commitment was principally characteristic of the March and April meetings, when directives stated that money market conditions were to be consistent with the growth targets for aggregates. Whether individual members of the Committee preferred a given money target because they agreed with the underlying money market condition associated with the target, or vice versa, is difficult to assess. The Committee was willing, however, to accept firmer conditions in late March and April in order to hold down the growth of money when projections indicated money was growing rapidly. As noted earlier, however, the Committee evidently was not willing to pursue a given quarterly target independent of the money market conditions that might be implied by the actions required to achieve the aggregate target.

\section{May through July: Emphasis on Moderating Pressure in Money and Credit Markets}

During this period, there was considerable concern by members of the Committee about pressures in the money markets and a possible liquidity crisis. Following the late May and June meetings, open market operations were aimed primarily at dealing with the unsettled atmosphere in the money and credit markets, and less emphasis was placed on achieving targets for monetary aggregates.

\section{Economic Outlook and Policy Decisions}

May 5 Meeting - Preliminary Commerce Department estimates indicated a decline in real GNP for the first quarter. Projections suggested little real economic growth in the second quarter, but some renewed growth in the second half of 1970 . It was noted at this meeting that prices continued to rise, although there were some moderating tendencies. The unemployment rate continued upward, reaching 4.8 per cent in April.

The unsettled condition of financial markets was also noted at this meeting. Most interest rates had risen from the April to May 5 meeting, counter to the general expectation of many market participants. Also, common stock market prices fell sharply in April and continued to fall in May.

Apparently, many factors contributed to the interest rate increases. Factors cited at the May 5 meeting included concern by market participants about the prospects for success of the Government's anti-inflationary program, the Cambodian military operations, and the unusually heavy demand for funds in the capital market. Rising interest rates appeared to be particularly unsettling due to the general expectation that continued declines in interest rates would accompany the slowdown in economic activity.

In light of these various developments, and in view of the fact that money was growing more rapidly than previously projected and that attempts to maintain the 3 per cent growth target for money might have undesired consequences, the Committee in. creased its second quarter growth target for money to 4 per cent. The staff analysis indicated that this rate could be achieved "with money market conditions similar to or slightly firmer than those currently prevailing." The Committee felt that the "demand for money" was greater than was thought earlier. ${ }^{13}$ According to a recent Federal Reserve report, "while anxieties in financial circles that a general liquidity squeeze was emerging proved to be clearly exaggerated, it is true nonetheless that their net effect was to cause a sharp increase in over-all demand for liquidity." 14

\footnotetext{
13 In this context, demand for credit is implied, rather than demand for monety. The ambiguity is widely discussed in economic literature.

1fFederal Reserve Board of Governors, The U.S. Economy in Transition-A Prelude to the Annual Report for $1970, \mathrm{p} .18$.
} 
The operating clause of the early May directive was quite similar to that of the previous month, except a proviso clause was added which stated:

.. that operations shall be modified as needed to moderate excessive pressures in financial markets, should they develop.

Mr. Francis dissented from the decision to accept the faster target rate of growth in money. He argued that a 4 per cent annual rate in the second quarter would imply a 6 per cent rate from February to June, and he considered such a rate excessive.

May 26 Meeting - It was observed that revised Commerce Department figures for real GNP showed a decline at a 3 per cent annual rate in the first quarter of 1970. Real GNP was still expected to rise in the second half of 1970 , although not as much as previously expected, with projections indicating no growth in the second quarter.

Uncertainties and strains surrounding the "liquidity crisis" continued to be primary concerns of the Committee at the late May meeting. The Committee stated a desire to see moderate growth in money and bank credit, but priority was to be given to the objective of moderating pressures in financial markets. The Committee acknowledged that this might bring a higher growth rate of money than the 4 per cent considered appropriate as the long-run objective. Projections indicated a 7 per cent rate of growth of money was likely in the second quarter, compared with an earlier target of 3 per cent, and indicated firmer money market conditions would develop if an effort were made to hit the 4 per cent target of the Committee.

June 23 Meeting - Financial markets were reported to have "calmed considerably" immediately following the May 26 meeting, and interest rates on many short-term instruments were tending to move downward. Long-term rates, however, continued to move upward, many reaching their 1970 peaks in June. New uncertainties were introduced into financial markets by the insolvency of the Penn Central Railroad, which caused the commercial paper market to be particularly sensitive. Yields on commercial paper tended to rise, as investors became more selective and aware of the risks involved in such paper.

In view of the uncertainties and strains in financial markets, the Committee again directed that open market operations be carried out with the objective of moderating these pressures. Analysis indicated growth of money at about a 5 per cent annual rate from June to September, assuming prevailing money market conditions were maintained. The Committee directed that to the extent possible this growth rate should be achieved while at the same time moderating market pressures. Thus, the target growth rate of money was increased from the 3 and 4 per cent rates targeted earlier in the year.

In addition to the actions taken by the Committee, two other actions were taken by the Federal Reserve. On the same day as the June Committee meeting, the Board of Governors suspended Regulation Q ceilings on 30- to 89-day maturity CD's and other single-maturity time deposits of $\$ 100,000$ or more. Also, in late June the administration of the discount window was temporarily relaxed, in order to accommodate banks which were lending to firms having difficulty in obtaining financing in the commercial paper market.

July 21 Meeting - Preliminary Commerce Department figures indicated that real GNP had increased only slightly in the second quarter, but projections continued to suggest that real GNP would pick up in the second half of 1970. Data for June showed that industrial production had declined further, but retail sales and housing starts had risen. The unemployment rate had declined to 4.7 per cent in June, from 5 per cent in May.

In view of the declining market interest rates, the Committee decided to place less emphasis on moderating market pressures and more emphasis on achieving the targets for monetary aggregates. The Committee agreed that a 5 per cent rate of growth in money remained the appropriate target for the third quarter (from June to September), but stated that if deviations from this target rate developed, they should be on the upside. The wording of the operating clause of the July directive was similar to the May 5 directive, calling for open market operations to be carried out to achieve growth targets for aggregates, but added a proviso clause that open market operations should be modified if financial pressures developed.

\section{Money Market Condutons and Monelary Aggregates}

From April through July, the money stock (old series) increased at a 2 per cent annual rate, while the adjusted bank credit proxy increased at an 8 per cent rate. The latter series was heavily influenced by the reintermediation of time deposits into banks. The monetary base grew at a 5.6 per cent rate in this 


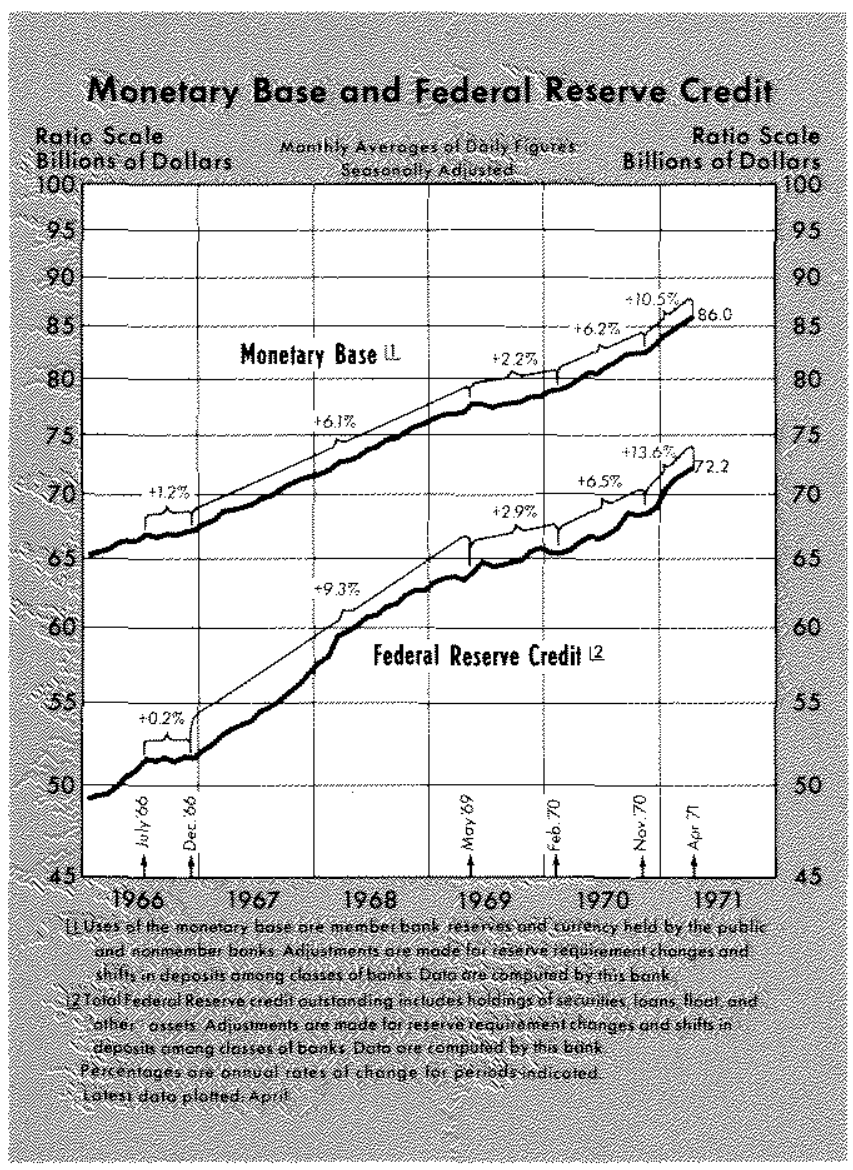

period. The substantially slower growth of money than the base is attributable largely to the rapid growth of time deposits. This rapid reintermediation of time deposit funds into banks absorbed reserves which otherwise could have supported an expansion in demand deposits. In general, short-term rates rose in April and May and tended to fall in June and July.

Open market operations were aimed primarily at moderating pressures in financial markets following the May 26 and June 23 meetings. Although at the time of the May 26 meeting a 7 per cent rate of growth in money was expected in the second quarter, the old series grew at a 4.2 per cent rate, close to the 4 per cent target desired (the revised data released in late November indicated the growth of money in this period was at about a 6 per cent annual rate).

\section{August through November: Easing in Money and Credit Markets}

In the four meetings from August 18 through November 17 , the emphasis on moderating money mar ket pressures was reduced, and longer-run objectives in terms of growth in aggregates were re-established.
In general, the directives in this period called for a dual policy objective of both "some easing of conditions in credit markets" and "moderate growth in money and attendant bank credit expansion."

Easing in credit markets was sought during this period because members of the Committee were concemed about the lack of decline in long-term interest rates. These members felt that it was desirable to have long-term rates decline in order to encourage recovery of residential construction and state and local government spending. In general, the instructions in the directives were as follows:

... the Committee seeks to promote some easing of conditions in credit markets and moderate growth in money and attendant bank credit expansion over the months ahead. System open market operations until the next meeting of the Committee shall be conducted with a view to maintaining bark reserves and market conditions consistent with those objectives. .

At times, these dual policy objectives could be in conflict with one another, but, in practice, they were not generally in conflict over this period. The demands for credit in the private economy continued to ease as the pace of economic activity continued to slow, at least partly in response to restrictive actions of late 1969.

\section{Economic Outlook and Policy Decisions}

August 18 Meeting - Projections for real GNP remained much the same in August as in July; that is, for some increase in real GNP in the second half of 1970, although below potential. It was noted that prices were still rising rapidly, but not as fast as earlier.

The money stock was expected to grow at an annual rate of about 4 per cent over the third quarter, if prevailing money market conditions were maintained, and more easing in money markets was believed needed to achieve a 5 per cent rate of growth in money. In the discussion by nembers of the Committee, an abatement of expectations of continuing inflation was noted, and it was agreed that policy should be directed at stimulating real growth of the economy, while at the same time being careful not to revive inflationary expectations. To stimulate real growth, the Committee directed open market operations to promote some easing in credit markets and to seek growth in the money stock at about a 5 per cent ammual rate. As in the July directive, the Committee stated that it preferred deviations from this target to be on the upside. 
Three members, Mr. Hayes, Mr. Brimmer, and Mr. Francis, dissented from this directive. They dissented primarily because "they were opposed to the promotion of some easing of conditions in credit markets' as a specific objective of Committee policy at this time." They considered this easing unnecessary to expand economic activity and involving "risk of rekindling inflationary expectations."

September 15 Meeting - At this meeting the Committee was informed that the money stock series contained a definite bias. Board of Govemors staff analysis indicated that further easing of money market conditions would be necessary in order for the money stock (roughly adjusted for bias) to grow at an amual rate of 5 per cent in the fourth quarter. The Committee decided that a 5 per cent growth in money and some casing in credit markets remained appropriate objectives for monetary policy in the fourth quater.

Some members felt money should grow somewhat faster than 5 per cent, while others felt that the money series should be de-emphasized at this time, in part due to the uncertainties relating to the forthcoming revision of the money stock series. Some members preferred that bank credit be given more weight, believing that reintermediation was about over. However, it was decided that for the present, "preponderant weight" should be given to the money stock "in assaying the implications of the behavior of financial aggregates for System operating decisions."

Mr. Hayes dissented from the directive, and expressed concern about again aiming toward "an easing of conditions in credit markets." He noted that interest rates had already fallen and "was not convinced that further easing would be required to achieve the objective. . . of moderate growth in money and bank credit." He also expressed concem over "the possible inflationary effects of a policy calling for progressive easing of credit conditions."

October 20 Meeting - A rise in real GNP at a 1.4 per cent anmual rate for the third quarter was indicated by preliminary Commerce Department figures. Also in September, there had been a fall in industrial production which was attributed primarily to the automobile strike. Unemployment had advanced in September to 5.5 per cent from 5.1 per cent in August. Real GNP was projected to move up slightly in the fourth quarter, but the auto strike clouded most statistics at the time.
Analysis presented indicated that if money market conditions similar to those recently prevailing were maintained, the money series (roughly adjusted) would grow at about a 5 per cent annual rate over the fourth quarter (from September to December). The Committee agreed that this remained an appropriate target accompanied by some easing in credit market conditions. As at the previous meeting, some members expressed a desire for a faster growth rate of money, while others wanted less emphasis given to achieving money growth targets.

Mr. Hayes again dissented for essentially the same reasons as the previous meeting. He did not disagree with a 5 per cent growth rate in money, but "he was concemed about the directive language reading "the Committee seeks to promote some easing of condi tions in credit markets, because it implied to him that a persistent push toward lower interest rates was intended, irrespective of market forces. Such a course, in his view, would involve undue risks of rekinding inflationary expectations and of weakening the international position of the dollar."

Substantial declines in short-term market interest rates had occurred so far in 1970 , reflecting the weak ness in demand for credit relative to supply. In response to similar supply and demand forces, the prime rate, the interest rate charged by banks on loans to their best business customers, had been reduced from 8 per cent to 7 siz per cent on September 21. On November 11 and succeeding days, the Federal Reserve Banks reduced their disconnt rate from 6 per cent to $5 \%$ per cent. On November 12, the prime bank loan rate was reduced to $7^{1 / 4}$ per cent, and only two weeks later was reduced to 7 per cent.

November 17 Meeting - Board of Governors staff projections reviewed by the Committee indicated that real GNP would not grow in the fourth quarter, and data for October showed a decline in retail sales and industrial production, while the unemployment rose further. The weaknesses in economic activity were at least partially caused by the automobile indastry strike. Projections suggested a rebound in economic activity in the first quarter of 1971 , assuming an end to the strike in the near future.

The money stock rose only slightly (revised series) in October, and analysis given at the November meeting indicated that further easing of money markets conditions would be necessary if even a 4 per cent rate of growth in money was sought in the fourth 
quarter. ${ }^{15}$ This shortfall below the 5 per cent target growth of money desired by the Committee was attributed to weakness in the demand for money and credit, mostly associated with the auto strike. Again, the view prevailed that the demand for money, or the "transactions needs" of the nonbank pablic, determines the growth of the money stock. This view appears to attribute relatively little significance to growth of bank reserves or the monetary base in the determination of the growth of money, even over a period of three or four months.

The Committee agreed that some further easing of credit and moderate growth in money remained appropriate targets, but felt that the actions that might be necessary in order to achieve a 5 per cent growth in money in both the fourth quarter of 1970 and the first quarter of 1971 could result in undesirable fluctuations in money and credit market conditions. The consensus of the Committee members was that a " 4 per cent growth rate in the fourth quarter would be acceptable if the results of operating experience over coming weeks bore out the indication of the staff analysis that attainment of a 5 per cent rate would require a sharp easing of money market conditions," This decision was made with the expectation that money would grow faster in the first quarter of 1971.

Mr. Maisel dissented from this directive because he favored growth of money in the fourth quarter "at least as high as the rate that had prevailed on the average in the first three quarters of the year." Thus, he favored growth in money at about a 6 per cent annual rate, whereas the Committee was willing to accept a 4 per cent rate of growth in the fourth quarter.

\section{Money Moket Conditions and \\ Monetary Aggtegates}

The money stock (revised series) grew at at 4.6 per cent annual rate from July to November, and the monetary base increased at a 4.2 per cent annual rate. Both short-term and long-term interest rates declined considerably during these months. For example, three-month Treasury bills fell from about 6.45 per cent in July to about 5.3 per cent in November, and yields on corporate Aaa bonds declined from 8.44 per cent to 8.05 per cent.

Following the August and September meetings, open market operations were aimed at easing credit markets and achieving moderate growth in money. Shortterm interest rates fell somewhat during this period,

\footnotetext{
15Reyision of the money series had been completed and was
} avalable to members at the November meeting.

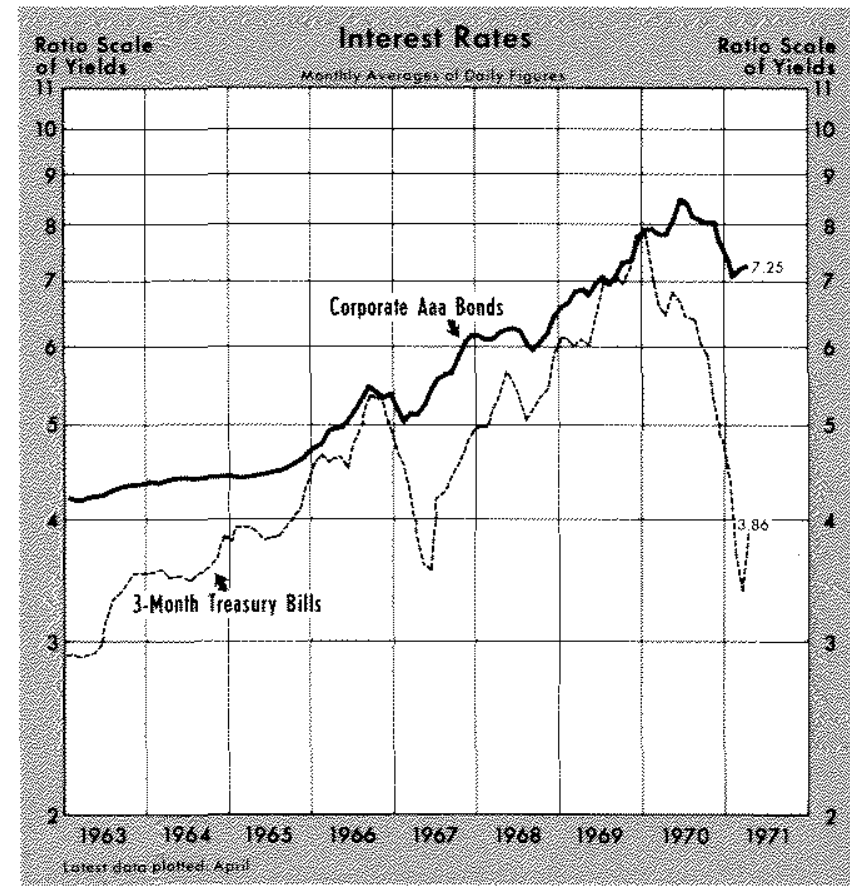

but yields on corporate and municipal bonds declined only slightly. At the mid-September meeting, a 4.5 per cent growth rate of money (old series) was expected for the third quarter (June to September), ${ }^{16}$ but a 5.2 per cent rate was obtained, close to the 5 per cent target desired. The revised money series grew at a 6.2 per cent rate in the third quarter.

Growth of the money stock fell short of expectations in October and November. Projections had indicated an increase at a 4.5 per cent rate in October (roughy adjusted series), while the actual rate was about 1 per cent (revised series). The shortfall was attributed to the weakness in credit demand associated with the automobile strike and slow business activity.

The Federal funds rate dropped sharply in this period; however, by observing the monetary base it is evident that the slow growth in money is attributable to the small increase in the monetary base in October and November. The base grew at only a 2 per cent annual rate in these two months.

Following the November meeting, easier money market conditions were sought in order to promote easing in credit markets and growth of money. Part of open market purchases were made in intermediateand long-term securities, which tend to lower longerterm interest rates. Both short-term and long-term interest rates fell substantially between the November and December meetings. 16. About 1 percentage point less was expected for the roughly
adjusted series, that is, 3.5 per cent. 


\section{December: Less Emphasis on Aggregates}

Less emphasis on aggregates prevailed during the December 15 meeting. The summary of discussion said, "the outlook for the monetary aggregates was particularly uncertain at this time, both because of the difficulties of assessing the precise impact on financial markets of the surge in activity expected in the aftermath of the automobile strike and because of the chuming in those markets that is typical of the period around the year-end." In view of these uncertainties, a number of Committee members suggested that less weight be given to aggregates and more to money market conditions.

The status of monetary aggregates as indicators of monetary policy actions was somewhat unclear at this juncture. Some members favored less emphasis only on a temporary basis, while others were for less emphasis on "more general grounds." Some members brought attention to more broadly defined monetary

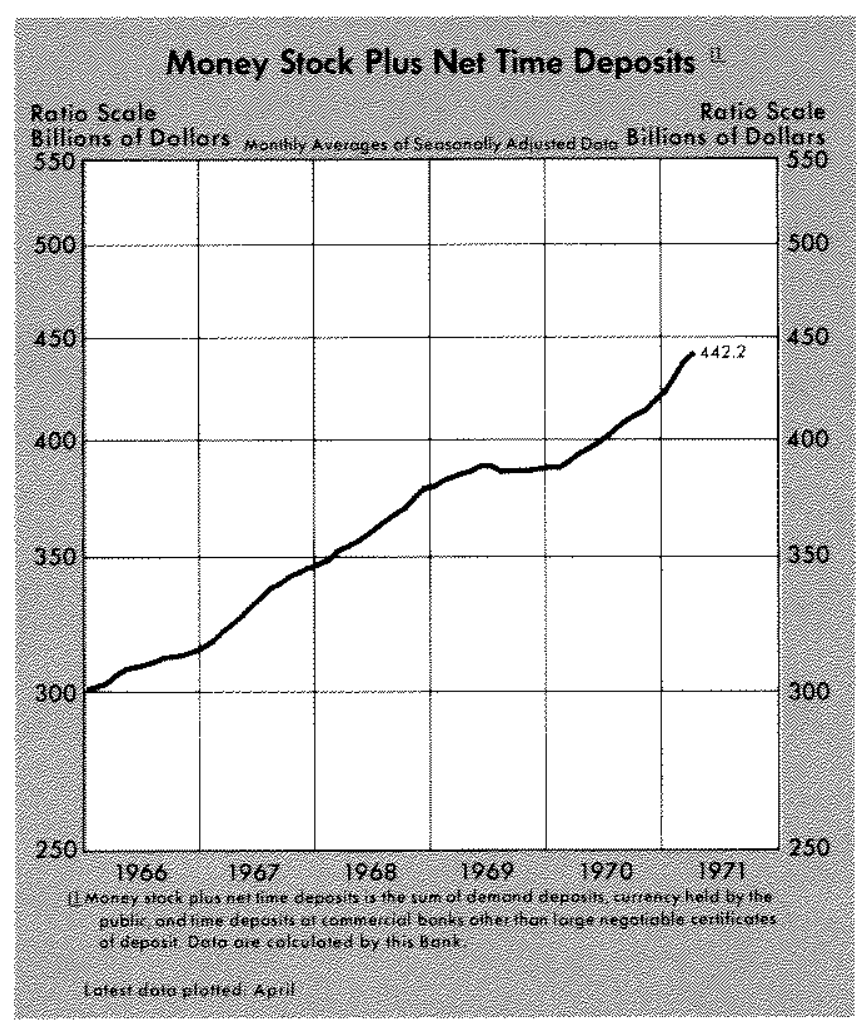

aggregates. For instance, money plus net time deposits grew at a rapid 10 per cent rate from February to December, partly reflecting the rapid reintermediation of time deposits into banks. ${ }^{17}$

There was some disagreement as to the appropriate targets for money in the fourth quarter of 1970 and

\footnotetext{
${ }^{17}$ Net time deposits are defined as total time deposits at com-
} mercial banks less large negotiable certificates of deposit. the first quarter of 1971 . Money was expected to grow faster than 5 per cent in the first quarter of 1971, and members concluded that movements in this series in the immediate future should appear consistent with the faster anticipated average rate. The Committee agreed that "money market conditions should be eased if it appeared that shortfalls from those growth paths were developing, but that otherwise operations should be directed at maintaining the conditions most recently attained." The operating clause of the December directive read:

System open market operations shall be conducted with a view to maintaining the recently attained money market conditions until the next meeting of the Committee, provided that the expected rates of growth in money and bank credit will at least be achieved.

Mr. Francis dissented from this directive, because he favored both maintaining a target 5 per cent annual rate of monetary growth and increasing the emphasis on money rather than reducing it. He expressed concern that a rate of growth in money at a rate faster than 5 per cent could possibly prolong inflation and even intensify it, while holding the growth in money to a 5 per cent rate "was likely to assure steady progress toward moderating price increases, along with a gradually increasing pace of expansion in real output."

At the December meeting, it was still expected that a 5 per cent growth of money would occur in the fourth quarter, even though the growth of money in October and November had been substantially below this target. However, growth of money was substantially less than expected in late December; for the fourth quarter, money grew at a 3.4 per cent rate. Immediately after the December meeting, open market operations were aimed at maintaining the prevailing money conditions. Since the demands for credit were continuing to ease substantially, market conditions remained easy. Nevertheless, Desk operations did not result in enough additional reserves to achieve the desired growth in money.

\section{CONCLUSON}

The year 1970 marked a "modest" beginning for the use of monetary aggregates in the formulation and implementation of monetary policy decisions. The emphasis on aggregates, however, varied during the year.

After the initial statement by the Committee at the January meeting, its position on monetary aggregates evolved; at the March and April meetings the objective of the directive was stated totally in terms of 
monetary aggregates. Beginning in May and continuing through the July meeting, the emphasis on aggregates was greatly reduced, and replaced by other short-term objectives such as moderating pressures in financial markets. However, targets for aggregates still were to be sought to the extent that they were consistent with these other objectives. The Conmittee raised the targets for money in several stages from a 3 per cent rate for the second quarter (March meeting) to a 5 per cent target for the third quarter at the July meeting. ${ }^{18}$ The emphasis on aggregates was somewhat reinstated at the August meeting and continued through the November meeting. However, the objective of achieving "some easing of conditions in credit markets" also was stated explicitly.

The Decenber meeting left the future status of monetary aggregates somewhat in doubt. The directive was again stated in terms of money market conditions; some Committee members expressed reservations about the use of monetary aggregates, and some desired more use of money market conditions. Part of the retum to primary emphasis on money market conditions at the end of the year may have been due to the data problems involving the revision of money stock series. As was noted earlier, according to the old series money growth had been fairly close to that

18The Committee desired to have deviations from the 5 per cent target on the upside. sought by the Committee, but with the revision, money had grown faster in the first three quarters of the year than desired.

Although growth of the money stock (old series) was quite close to the quarterly targets desired by the Committee, by looking more closely one could argue that this was partly an accident. For example, at the May 26 meeting a 7 per cent growth rate of money was expected for the second quarter. An un expected shortfall in money occurred in June, and a 4.2 per cent rate was achieved in the second quarter, quite close to the earlier 4 per cent target. Growth of aggregates for the fourth quarter of 1970 was considerably under-achieved. Growth of money in October and November fell short of expectations, even though money market conditions eased as was called for in the directive. Despite these shortfalls, at the December 15 meeting, a 5 per cent rate of money growth was expected for the pertod September to December, but only a 3.4 per cent rate (revised series) was achieved.

These developments give the impression that control methods for money have yet to be perfected. Part of the problem may lie with the "money market conditions" approach. A more direct approach such as controlling bank reserves or the monetary base may be a more reliable method for controlling the money stock. 